\title{
Transition to Fiscal Federalism in Nepal: Western Insights in the Definition of Intergovernmental Transfers
}

\author{
Camille Van Hove ${ }^{1} \&$ Julien Vandernoot ${ }^{1}$ \\ ${ }^{1}$ Warocqué School of Business and Economics, University of Mons, Mons, Belgium \\ Correspondence: Julien Vandernoot, Warocqué School of Business and Economics, University of Mons, Place \\ Warocqué, 17, 7000 Mons, Belgium. Tel: 32-6-537-3269. E-mail: julien.vandernoot@umons.ac.be
}

Received: February 16, 2015

Accepted: March 5, 2015

Online Published: March 9, 2015

doi:10.5430/rwe.v6n1p190

URL: http://dx.doi.org/10.5430/rwe.v6n1p190

\begin{abstract}
In 2008, Nepal was declared a "federal democratic republic". However, since then, political differences have been curbing the establishment of a federal model in the country. While studies generally focus on the political aspects of this issue, this paper is based on an economic approach. Using the fiscal federalism literature and the practices of western federal countries, the article studies the funding systems that could be put in place to support the various regions of Nepal. Seven criteria for the distribution of funding between provinces are assessed. A principle of pure "fair return" seems difficult to implement due to the lack of revenue of some areas. Strong equalization transfers will be needed in order to ensure, at least, a status quo for everyone. By any criterion, the province including Kathmandu district has to face a gap between revenue and expenditure. This can be explained by the high level of expenditure needed in Kathmandu. The topic of this research has been little explored to date, despite its importance for ensuring an efficient federal model in Nepal.
\end{abstract}

Keywords: fiscal federalism, Nepal, funding systems, federal countries, public finance

\section{Introduction}

Since the $4^{\text {th }}$ Amendment of the Interim Constitution in May 2008, Nepal has become a federal republic. So far, efforts have been made in order to define the structure of the federal State. As the limits of the Provinces are not defined yet, many questions remain unsolved. This research is aimed at working on financing issues. How can Nepal finance its sub-national level? To which extent can the federal level allow accountability to lower level? At first, literature will be briefly reviewed. Then, the experience of Western states will be acknowledged. Lessons learned from these theoretical reviews will help us to carry out the next stage of our research, namely comparing different criteria used for revenue sharing or equalizing transfers. Information about revenue and expenditure at district levels is given by consolidated financial statements of 2011-2012 Fiscal Year (Government of Nepal, 2012). As highlighted above, provincial boundaries have not yet been legally defined. We will therefore base our research on the proposal made by political parties a few days before the dissolution of the Constituent Assembly of Nepal in 2012, disseminated by Chr. Michielsen Institute (Hatlebakk \& Ringal, 2013). (Note 1)

\section{Fiscal Federalism, Financing Systems and Solidarity Mechanisms: Brief Overview}

Fiscal relations between sub-national governments or with the Central one vary. The issue can be studied through the level of solidarity, autonomy, accountability and competition that the legislator wants to give to the different levels (Pagano, 2002). Solidarity means that, no matter how much it contributes to the total revenue of government, each entity will receive money in order to support its expenditure. The concept of autonomy refers to the ability of lower levels of government to levy taxes, and modify tax rate and base. Financial accountability goes a step further and leads to a decline of solidarity: entities have to finance their public goods and services with the revenue they generate and cannot rely on others. Competition among governments is more closely related to the concept of autonomy and can occur through taxes or provision of public goods and services (Denil et al., 2005).

In many western countries, solidarity mechanisms are used to equalize fiscal capacity of the different entities or to make sure these entities have enough revenue to face higher needs. The transfers can be vertical (from the central level) or horizontal (between entities that are at the same level of government). The criteria for allocating funds can be based on the entities' needs or financial capacity. 
Considering the theory draws on western practices, the next part of this article studies these more closely.

\section{Western Practices of Fiscal Federalism}

The first country reviewed is Germany, whose territory is divided into 16 Länder. Some prerogatives are only conferred on the central state (Bund), while Landër are assigned the "exercise of governmental power and accomplishment of State missions" unless the fundamental law devotes power to the Bund (Basic Law for the Federal Republic of Germany, 1949). The financing system is characterized by a high level of accountability even if the Landër's autonomy regarding revenue is limited (tax rates are defined at the Bund level and applied in each Land) (Bönke et al., 2013). A share of common taxes is given to the Länder which divide it according to a federal law adopted by the two government houses (Spahn, 2012). Horizontal equalization transfers are then organized in order to ensure to all Länder a minimum of $95 \%$ of the average fiscal capacity. The actual fiscal capacity of each Land is compared to a point of reference, which is the average fiscal capacity per capita multiplied by the population of each entity. The difference is partially transferred to or from the Land, depending on whether the fiscal capacity per capita is above or below the national average. The last stage of German financing system includes the vertical transfers that can be applied if wide disparities still exist (Guihéry, 2005).

Belgium is divided into Regions (on a geographical basis) and Communities (cultural and linguistic affiliation), which are assigned different areas of competence. Two financing regimes coexist, the Regional one being characterized by more autonomy and accountability than the Community one. A reform has been adopted on 6 January 2014, with the aim to increase the fiscal autonomy of Belgian Regions. New prerogatives have been attributed to sub-national levels of government and the financing mechanisms have been modified. The Regional financing system uses revenue sharing, solidarity transfers and devolved taxes. A part of the revenue from the personal income tax is shared between the Regions according to their contribution to it. These are autonomous for some taxes devolved (base, rate and exonerations) and can also create regional taxes. In addition to this, equalization transfers are made to poorer Regions in terms of contribution to the personal income tax. Regions whose share of the personal income tax is lower than their share in the total population receive $80 \%$ of this difference multiplied by an amount "referring to fiscal autonomy, grants divided according to a fiscal key and 50\% of the new part of IPP attributed to Communities" (Bayenet \& Pagano, 2013). As a city-state (see below), Brussel takes form of a federal unit. However, additional financing mechanisms are applied to the Brussels-Capital Region because of its particularities as a capital. The financing system of Communities is characterized by an implicit solidarity. A part of their revenue comes from "masse TVA" (VAT share) and radio-TV license fees, which are distributed based on the percentage of students enrolled in compulsory education in each community. The amount attributed evolves in line with demographic growth and $91 \%$ of the economic growth. Other revenues are distributed depending on the contribution of each Community to the personal income tax. They evolve taking into account the inflation and $82.5 \%$ of economic growth. They also receive other grants from the central level and, unlike Regions, they cannot levy their own taxes (Bayenet \& Pagano, 2013).

Spain is divided into 17 Autonomous Communities, which have progressively received more competences. Two financing regimes coexist in Spain: a common and a foral one. While the first is applied in almost all Autonomous Communities, the second only covers Basque Country and Foral Community of Navarre. The foral Communities levy taxes and transfer a share of their revenue to the Central state. Some principles laid down in the law aims at protecting solidarity, fiscal harmony and collaboration between entities. The common regime gives Autonomous Communities (CA) fiscal autonomy regarding to some tax bases, rates and deductions, as well as a share of some taxes. The first financing mechanism is the public services guarantee fund: each CA contributes to $75 \%$ of the devolved taxes, while the other $25 \%$ are financed by the Central state. The money is divided among the regions belonging to the common regime according to their "adjusted population": population weighted by the area, the population dispersal, the insularity and the age structure (Martinez et al., 2014). A second fund, financed by the Central State, is based on the difference between fiscal capacities of autonomous communities, added to the revenue attributed by the public services guarantee fund and their needs (Santiuste Vicario, 2011). Autonomous convergence funds are divided into the competitiveness fund and the cooperation fund. The first one is aimed at ensuring harmony in regional development and economic growth, and convergence across regions. To be eligible, a CA has to have a certain level of GDP, population density or growth. Two thirds of the fund is transferred to the autonomous communities depending on their share of the population, weighted by the difference in terms of GDP per capita. The last third is distributed among the Autonomous Communities whose population growth is lower than $50 \%$ of the average based on their share of population. The competitiveness fund is aimed at financing equally citizens' needs, avoiding fiscal competition and promoting autonomy. An Autonomous Community is eligible if its homogeneous financing index (HFI) is lower than 1 or than the fiscal capacity index (FCI). Calculations of these indexes are given 
by the Law of 18 December 2009 (Law 22/2009). An amount is also granted in order to avoid the Community to have per capita revenues that are lower than the average due to its participation to the different financing mechanisms (Martinez et al., 2014). An Inter-territorial Compensation fund provides a certain amount to the Communities that are eligible for the European structural funds, depending on several indicators (area, net migration, unemployment levels...) (Law 22/2001). Since 2009, additional means have been allocated to Regions belonging to the Common Regime in order to strengthen the Welfare state. These are distributed based on different criteria: variation of the adjusted population in the area in comparison with the same variable for all Autonomous Communities $(75 \%)$, share of the adjusted population in the total $(12.5 \%)$, share of the potentially dependent population (10\%), total and share of the population recognized as dependent $(2.5 \%)$. Additional resources are also attributed depending on the population dispersal, density and for linguistic normalization (Law 22/2009).

Canada is divided into 10 Provinces and 3 Territories. The Federal State can legislate in areas that are not attributed to the sub-national Provinces by the law. A few competences are also common to both the Central State and the Provinces (Constitution Act, 1867). Provinces are attributed high level of autonomy when it comes to taxes. Three transfers from the Central State are dedicated to Provinces: equalization, Canada Social Transfer and Canada Health Transfer. The objective of equalization payments is "to ensure that provincial governments have sufficient revenues to provide reasonably comparable levels of public services at reasonably comparable levels of taxation" (Constitution Act, 1982, Article 36(2)). Difference between annual return of revenue and the same variable for the entire Land, weighted by the share of population, is calculated for each source of revenue and summed for each Province. Natural resources are taken into account only if it leads to a higher amount. If the sum is negative, it means that the area is not eligible to equalization payments. The sum is adjusted based on Article 3.4 of Federal-Provincial Fiscal Arrangements Act of 1985 to provide the amount transferred to each Province. Equalization offset payments are also attributed to Nova Scotia, Newfoundland and Labrador as a result of the agreement between these provinces and the Canadian State (Nova Scotia and Newfoundland and Labrador Additional Fiscal Equalization Offset Payments Act, 2005). Another system is applied to the Territories. Canada Social Transfer (CST) and Canada Health Transfer (CHT) are also attributed to sub-national governments. CHT is aimed at ensuring the respect of principles defined in the Canada Health Act and the provision of quality information and care for all citizens. Additional payments are aimed at adding flexibility in the provision of health care. CST, whose calculation is similar to CHT's one, is aimed at ensuring flexibility and unconditional (in terms of residency) assistance in social matters (Federal-Provincial Fiscal Arrangements Act, 1985).

Switzerland is a Confederation of 26 Cantons. Attribution of prerogatives to Swiss Cantons or Communes follows the principle of subsidiarity: as long as the lowest level can act better, there is no reason to centralize a function. Some taxes can be levied by the central level. As soon as the Confederation decides to tax in an authorized field, Cantons and Communes cannot levy taxes in this field (Federal Act, 1999). Equalization mechanisms also exist in Switzerland. In order to define which entity can receive transfers, "resources potential" is calculated for each Canton. Standardized fiscal rate is applied to these data; the total is divided by the population and compared to the national average according to the national average index which indicates 100. If the resources index of an entity falls below 100 , this one is called "low resources potential canton" and receives transfers. If the index is greater than 100, the Canton is considered to have a "high resources potential" and will contribute to the financing of equalization transfers. Calculations are defined by a Federal Law and the Cantons are expected to meet $85 \%$ of the national average after equalization transfers (Federal Law on financial equalization and compensation for financial burdens, 2003). Additional transfers are also aimed at compensating financial burdens supported by some regions due to their geo-topographic or socio-demographic characteristics. The variables taken into consideration are altitude (percentage of people living higher than 800 meters), declivity, housing structures and population density concerning geo-topographic burdens. A budget is defined for compensation transfers for socio-demographic burdens and the "Villes-Centres". Two thirds are dedicated to the socio-demographic burdens, compensated through transfers calculated on the basis of poverty, age structure and foreigners integration. The last third is used to finance excessive burdens of "Villes-Centres", for which calculations take into consideration employment rate, population and population density (Federal Order on financial equalization and compensation for financial burdens, 2007).

This overview of western practices of fiscal federalism, financing systems and solidarity mechanisms highlights a great heterogeneity in the application of federalism principles. Indeed, while some countries base their equalization transfers on, among others, personal income tax, corporate income tax, value added tax, others use poverty, geo-topographical costs, or socio-demographical costs as a basis.

Many mechanisms overlap in order to ensure sufficient money to each entity. In some countries a "paradox of revenue" can even be noticed. A paradox of revenue occurs when an entity initially poorer than another one becomes, 
after receiving financing, richer. This happens for example in Belgium, Spain and Germany (Vandernoot, 2014). Autonomy and accountability attributed to the sub-national governments are also quite variable. Note than the situation has changed throughout the history of these countries.

\section{Contextualization}

The federalization process of Nepal started with the $4^{\text {th }}$ Amendment of the Interim Constitution in 2008. A Constituent Assembly was elected. However, even after many discussions, a consensus is still hard to find. The main problem remains defining the boarders of the future entities. There are two major points of view: a division based on economic viability of Provinces and another one based on ethnicity and demands of people (Hatlebakk \& Ringal, 2013).

The model selected in this paper is the one resulting from a consensus of different political parties, which divides the country into 11 Provinces. The division also includes a reorganization of the districts' frontiers. Considering the lack of more detailed information, we have based our approach on the situation as presented by the Chr. Michelsen Institute, stipulating that districts are considered to be located in the provinces in which most of its population will live (Hatlebakk \& Ringal, 2013).

\section{Methodology and Assumptions}

Our purpose is to analyze how different criteria can be taken into account for sharing revenue. Data provided by the consolidated financial statements of 2011-2012 fiscal year allow us to draw some comparisons between the different criteria, in terms of per capita revenue (equalizing the fiscal capacity) or lack of revenue per capita (reaching the needs of expenditure). Due to limited available information, assumptions have been drawn: (1) the total revenue equals the total expenditure (the deficit of Nepalese government is not taken into account); (2) the total revenue is shared among the Provinces; (3) the expenditure reflects the actual needs of each Province.

The total revenue will not be shared among the different entities and expenditure of the Central government will not necessarily reflect actual needs. However, this approach allows us to draw comparisons and recommendations for the future federal structure of Nepal.

\section{Comparison of Different Criteria}

The first criterion assessed refers to the principle of accountability: each entity has to support its expenditure with its own revenue. It can be applied through revenue sharing (see Belgium case) or though autonomy in the levying of tax. The amount per capita attributed to a Province and the difference between per capita expenditure and revenue are shown in the table below (Table 1).

Table 1. Application Key 1a

\begin{tabular}{lccc}
\hline & $\begin{array}{c}\text { Per capita } \text { expenditure } \\
2011-2012(\mathrm{NPR})\end{array}$ & $\begin{array}{c}\text { Per capita revenue } \\
\text { Key 1a (NPR) }\end{array}$ & Difference (NPR) \\
\hline Limbuwan & 10110.21 & 601.44 & -9508.77 \\
Kirat & 9197.08 & 430.87 & -8766.21 \\
Kochila & 5642.85 & 9937.32 & 4294.47 \\
Madhes & 4343.75 & 17062.50 & 12718.75 \\
Tamsaling & 8737.22 & 3972.94 & -4764.28 \\
Narayani & 38519.35 & 38036.87 & -482.48 \\
Tamuwan & 9856.34 & 2065.95 & -7790.39 \\
Magarat & 8506.19 & 460.16 & -8046.03 \\
Tharuwan & 6193.78 & 8272.56 & 2078.78 \\
Khaptad & 12141.75 & 419.94 & -11721.81 \\
Karnali & 7963.27 & 1159.61 & -6803.66 \\
NEPAL & 12037.18 & 12037.18 & - \\
\hline
\end{tabular}

Government of Nepal, 2012; Own calculations 
The application of Key 1a (Table 1) leads to a high per capita revenue for the Provinces of Narayani (NPR 38 036.87) and Madhes (NPR 17 062.50). A disparity in the level of revenue attributed according to this key can be noticed: while Narayani receives NPR 38036.87 per capita, Khaptad receives only NPR 419.94. (Note 2) The amount transferred allows only three areas to get more than they need per capita: Madhes (+ NPR 12 718.75), Kochila (+ NPR 4 294.47), and Tharuwan (+ NPR 2 078.78). It leads, in some Provinces, to a high lack of revenue (Khaptad, - NPR 11 721.81).

The next criterion is built on some mechanisms used in Germany and Belgium. Key $1 \mathrm{~b}$ (Table 2) is calculated in order to increase the fiscal capacity of the entities whose revenue per capita are lower than the average. The total revenue of an entity is compared to the average revenue per capita multiplied by the population of the Province (reference amount). If the difference is negative, the Province receives compensation so that its revenue equals $80 \%$ of the national level. If the difference is positive, the Province has to contribute to the funds. Note that the national fiscal capacity per capita equals NPR 12 037.81.

Table 2. Application Key $1 \mathrm{~b}$

\begin{tabular}{lcccc}
\hline & $\begin{array}{c}\text { Pop. } 2011 \\
(100 \text { 000 inhab. })\end{array}$ & $\begin{array}{c}\text { Per capita revenue } \\
\text { application Key 1b } \\
\text { (NPR) }\end{array}$ & $\begin{array}{c}\text { Per capita Expenditure } \\
\text { 2011-2012 (NPR) }\end{array}$ & $\begin{array}{c}\text { Difference } \\
(\text { NPR })\end{array}$ \\
\hline Limbuwan & 10.33 & 9750.03 & 10110.21 & -360.17 \\
Kirat & 9.6 & 9715.92 & 9197.08 & 518.84 \\
Kochila & 25.42 & 11617.21 & 5642.85 & 5974.36 \\
Madhes & 54.04 & 13042.25 & 4343.75 & 8698.49 \\
Tamsaling & 13.98 & 10424.33 & 8737.22 & 1687.11 \\
Narayani & 41.31 & 17237.12 & 38519.35 & -21282.23 \\
Tamuwan & 17.1 & 10042.94 & 9856.34 & 186.59 \\
Magarat & 15.74 & 9721.78 & 8506.19 & 1215.58 \\
Tharuwan & 35.66 & 11284.26 & 6193.78 & 5090.48 \\
Khaptad & 11.73 & 9713.74 & 12141.75 & -2428.02 \\
Karnali & 30.04 & 9861.67 & 7963.27 & 1898.40 \\
NEPAL & 264.95 & & 12037.18 & - \\
\hline
\end{tabular}

Government of Nepal, 2012; Own calculations

With this key, each Province reaches a level of revenue per inhabitant equal to $80 \%$ of the national level. The amounts received by Narayani and Madhes are lower than in the previous case (key 1A), because they now have to support the equalizing transfers dedicated to the other provinces. The lack of revenue of Narayani increases from NPR 482.48 to NPR 21282.23 per capita. However, this key allows all other entities but Limbuwan (- NPR 360.17) and Khaptad (-NPR 2428.02 ) to meet their needs. Increasing the proportion of compensation from $80 \%$ to $90 \%$ would reduce the problems met by Khaptad, creates a surplus for Limbuwan, but increases the financial needs of Narayani.

Economic indicators show that the contribution of each Province to the national GDP is less unequal than the share of fiscal revenue. It could be interesting to evaluate the amount of money received by each entity if the redistribution key was based on GDP. That is the point of Key 2a (Table 3). Key 2b (Table 4) applies more solidarity-based transfers: the more the entity is rich in terms of GDP, the less money it receives from the government. It is clear that such a criterion would be applied only on a part of the revenue. However we applied it to the total in order to compare it with the total expenditure. 
Table 3. Application Key 2a

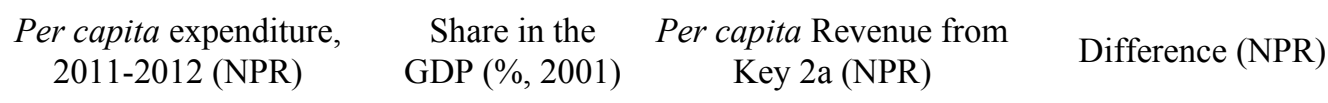

\begin{tabular}{lcccc}
\hline Limbuwan & 10110.21 & $4.09 \%$ & 12633.56 & 2523.35 \\
Kirat & 9197.08 & $3.33 \%$ & 11060.28 & 1863.20 \\
Kochila & 5642.85 & $10.29 \%$ & 12914.18 & 7271.33 \\
Madhes & 4343.75 & $16.58 \%$ & 9784.86 & 5441.11 \\
Tamsaling & 8737.22 & $5.82 \%$ & 13263.23 & 4526.01 \\
Narayani & 38519.35 & $23.35 \%$ & 18026.20 & -20493.15 \\
Tamuwan & 9856.34 & $7.52 \%$ & 14020.60 & 4164.26 \\
Magarat & 8506.19 & $5.16 \%$ & 10448.92 & 1942.73 \\
Tharuwan & 6193.78 & $11.96 \%$ & 10698.96 & 4505.18 \\
Khaptad & 12141.75 & $2.93 \%$ & 7960.83 & -4180.92 \\
Karnali & 7963.27 & $8.98 \%$ & 9530.09 & 1566.82 \\
NEPAL & 12037.18 & $100.00 \%$ & - & - \\
\hline
\end{tabular}

United Nations Development Program, 2004; Government of Nepal, 2012; Own calculations

The application of the Key 2a (Table 3) allows some Provinces to increase their revenue per capita. 9 out of 11 entities are able to meet their needs. However, once again, Narayani has a lack of revenue per capita which amounts to NPR 20 493.15. Khaptad also needs more revenue to cover its expenditure (- NPR 4 180.92). The application of this key induces more equalization than the first one and ensures more viability to the different provinces, except for Narayani. Key $2 \mathrm{~b}$ is more solidarity-based (Table 4 below) and allows all provinces to meet their level of expenditure, except Narayani which has to face a higher lack of revenue than with previous keys.

Table 4. Application Key $2 \mathrm{~b}$

\begin{tabular}{lccccc}
\hline & $\begin{array}{c}\text { Population 2011 } \\
\text { (100000 inhab.) }\end{array}$ & $\begin{array}{c}\text { Per capita } \\
\text { expenditure } \\
2011-2012(\mathrm{NPR})\end{array}$ & $\begin{array}{c}\text { Index of Per capita } \\
\text { GDP (2001, } 100= \\
\text { Nepal) }\end{array}$ & $\begin{array}{c}\text { Per capita } \\
\text { Revenue from Key } \\
\text { 2b (NPR) }\end{array}$ & $\begin{array}{c}\text { Difference } \\
\text { (NPR) }\end{array}$ \\
\hline Limbuwan & 10.33 & 10110.21 & 105.02 & 11440.81 & 1330.60 \\
Kirat & 9.6 & 9197.08 & 91.94 & 13014.08 & 3817.00 \\
Kochila & 25.42 & 5642.85 & 107.36 & 11160.19 & 5517.34 \\
Madhes & 54.04 & 4343.75 & 81.34 & 14289.51 & 9945.76 \\
Tamsaling & 13.98 & 8737.22 & 110.26 & 10811.14 & 2073.92 \\
Narayani & 41.31 & 38519.35 & 149.85 & 6048.17 & -32471.18 \\
Tamuwan & 17.1 & 9856.34 & 116.55 & 10053.76 & 197.42 \\
Magarat & 15.74 & 8506.19 & 86.86 & 13625.44 & 5119.25 \\
Tharuwan & 35.66 & 6193.78 & 88.94 & 13375.41 & 7181.63 \\
Khaptad & 11.73 & 12141.75 & 66.18 & 16113.54 & 3971.79 \\
Karnali & 30.04 & 7963.27 & 79.22 & 14544.28 & 6581.01 \\
NEPAL & 264.95 & 12037.18 & 100 & - & - \\
\hline
\end{tabular}

United Nations Development Program, 2004; Government of Nepal, 2012; Own calculations 
In Spain, population is taken into account in the first mechanism of redistribution. Adjusted population is calculated, taken into account density, age structure... The next tables will consider two types of transfers: population-based (Key 3a, Table 5) and a combination of population-based and geographic-based criteria (Key 3b, Table 6).

Table 5. Application Key 3a

\begin{tabular}{lcccc}
\hline & $\begin{array}{c}\text { Population } \\
2011 \text { (100 } 000 \\
\text { inhab.) }\end{array}$ & $\begin{array}{c}\text { Per capita expenditure } \\
(2011-2012, \text { NPR) }\end{array}$ & $\begin{array}{c}\text { Per capita Revenue } \\
\text { from Key 3a (NPR) }\end{array}$ & Difference (NPR) \\
\hline Limbuwan & 10.33 & 10110.21 & 12037.18 & 1926.97 \\
Kirat & 9.6 & 9197.08 & 12037.18 & 2840.10 \\
Kochila & 25.42 & 5642.85 & 12037.18 & 6394.33 \\
Madhes & 54.04 & 4343.75 & 12037.18 & 7693.43 \\
Tamsaling & 13.98 & 8737.22 & 12037.18 & 3299.96 \\
Narayani & 41.31 & 38519.35 & 12037.18 & -26482.17 \\
Tamuwan & 17.1 & 9856.34 & 12037.18 & 2180.84 \\
Magarat & 15.74 & 8506.19 & 12037.18 & 3530.99 \\
Tharuwan & 35.66 & 6193.78 & 12037.18 & 5843.40 \\
Khaptad & 11.73 & 12141.75 & 12037.18 & -104.57 \\
Karnali & 30.04 & 7963.27 & 12037.18 & 4073.91 \\
NEPAL & 264.95 & 12037.18 & 12037.18 & - \\
\hline
\end{tabular}

Central bureau of statistics, 2011; Government of Nepal, 2012; Own calculations

Key $3 \mathrm{a}$ (see Table 5 above) ensures an equal amount of money per inhabitant. However, it does not mean that each province is economically viable. This type of transfer clearly shows that some areas have higher levels of expenditure per inhabitant than others. For example, Madhes needs less than $40 \%$ of the money transferred per inhabitant (NPR 4 343.75), while Narayani needs a three times greater amount (NPR 38 519.35). Provinces sparsely populated but characterized by a large area could be at a disadvantage. In order to ensure them a sufficient amount, the share in the total area has been used as second criterion. 75\% of the money is attributed based on the population and $25 \%$ based on the total area. Table 6 below shows the results.

Table 6. Application Key 3b

\begin{tabular}{lccccc}
\hline & $\begin{array}{c}\text { Per capita } \\
\text { expenditure } \\
2011-2012(\mathrm{NPR})\end{array}$ & $\begin{array}{c}\text { Share in } \\
\text { population } \\
(\%, 2011)\end{array}$ & $\begin{array}{c}\text { Share in area } \\
(\%)\end{array}$ & $\begin{array}{c}\text { Per capita } \text { Revenue } \\
\text { from Key 3b (NPR) }\end{array}$ & $\begin{array}{c}\text { Difference } \\
(\mathrm{NPR})\end{array}$ \\
\hline Limbuwan & 10110.21 & 3.90 & 7.91 & 15130.43 & 5020.22 \\
Kirat & 9197.08 & 3.62 & 6.49 & 14414.13 & 5217.05 \\
Kochila & 5642.85 & 9.59 & 3.21 & 10033.51 & 4390.66 \\
Madhes & 4343.75 & 20.40 & 6.56 & 9996.31 & 5652.56 \\
Tamsaling & 8737.22 & 5.28 & 7.96 & 13564.01 & 4826.79 \\
Narayani & 38519.35 & 15.59 & 5.84 & 10154.32 & -28365.03 \\
Tamuwan & 9856.34 & 6.45 & 11.10 & 14205.19 & 4348.85 \\
Magarat & 8506.19 & 5.94 & 7.46 & 12808.57 & 4302.38 \\
Tharuwan & 6193.78 & 13.46 & 8.55 & 10938.40 & 4744.62 \\
Khaptad & 12141.75 & 4.43 & 18.71 & 21748.02 & 9606.27 \\
Karnali & 7963.27 & 11.34 & 16.22 & 13334.49 & 5371.22 \\
NEPAL & 12037.18 & 100.00 & 100.00 & 12037.18 & - \\
\hline
\end{tabular}

CBS, 2011; Gurung, 2008; Government of Nepal, 2012; Own calculations 
In comparison with the previous Key ( $3 \mathrm{a}$, Table 5), an increase of revenue for some areas can be noticed. The most important change seems to occur in Khaptad. This province, located in the Western part of the country, is characterized by a large area $(18.71 \%)$, but with few inhabitants $(4.43 \%)$. The key 3a leads to a lack of revenue in this Province, while the key $3 \mathrm{~b}$ creates a surplus. However, the gap that Narayani has to fill in is greater in the second option. Other criteria could be added, depending on the prerogatives that will be devolved to Provinces.

Finally, as Nepal is a developing country, inclusion of Human Development Index (HDI) in the transfer calculations could be interesting. We refer to this indicator because of its multidimensionality: it takes into account health, education and wealth per inhabitant (Smith et al., 2013). As the results are similar to other keys, we do not include the table here. Once again, the amounts transferred allow all Provinces but Narayani (which includes Kathmandu district and its valley) to meet their needs. Expenditure needed in this district is really high: NPR 77331.04 . However, Limbuwan district (part of Kathmandu Valley), with high per capita revenue, helps the Narayani Province to reduce its lack of funds. Without Kathmandu, Narayani Province would create a surplus if we apply Key 1a. The place of Kathmandu in the future federal organization needs to be clearly defined: will it be included in Narayani Province or not? Does it need to become a city-state or a federal district? The theoretical literature about this topic is quite scarce. Three categories can be identified: "federal district", "city-state" and "capital city in a federal state" (Van Wynsberghe, 2003). A federal district refers to the view of the capital as an entity subject to specific provisions as capital. The city-state is a federal entity which is given comparable prerogatives to other entities. The third option is to consider the capital as an "ordinary" city (Van Wynsberghe, 2003).

\section{Conclusion}

This paper was aimed at investigating the financing mechanisms that are likely to be applied in Nepal. This topic has not been discussed a lot so far due to the lack of consensus between political parties. Western practice and literature review allow us to be aware of the various ways to implement financing mechanisms in federal countries. The transfers can be based on financial capacity of the sub-national government or their needs. We assessed keys referring to both starting points.

The first key (key 1a) applies a pure principle of "fair return". As we have seen, it leads to a tricky situation for several entities. Moreover, our calculations show that the revenue of the entities is quite unstable from one year to another, which could lead to even more uncertainty. In order to ensure entities stable and sufficient revenue, other keys may have to be added. Key $1 \mathrm{~b}$ to $2 \mathrm{~b}$ are influenced by the economic climate. We must be careful and investigate the extent to which the economic climate influences the revenue. Key $3 \mathrm{a}$, based on the population, has a strong equalizing power in terms of revenue per capita. However, as the needs are quite variable across the Provinces, it does not mean that the total expenditure needed will be met. Including the territorial criterion in our calculations seems to help entities to meet their needs, except Narayani. Other variables (such as age structure) should be included, depending on the prerogatives that will be devolved. Key 4 could be used as criteria for equalizing transfers, in addition to other revenue. The example of Swiss transfers compensating geo-topographic and socio-demographic burdens can be helpful for the financing of remote areas and the huge municipalities.

Further research in the field of fiscal federalism in Nepal could study the financial flows between the Nepalese sub-national entities once the territorial division and the financing of these entities have been accurately defined.

Nepal is at the premises of a great change as regards its state structure. Defining the intergovernmental transfers will be a tricky task if the country wants to enjoy the benefits of fiscal federalism and ensure a prosperous development of its entire territory.

\section{References}

Bahl, R. (1999). Fiscal decentralization as Development policy. Public Budgeting and finance, 19, 59-75. http://dx.doi.org/10.1046/j.0275-1100.1999.01163.x

Bayenet, B., \& Pagano, G. (2013). Le financement des entités fédérées dans l'accord de réformes institutionnelles du 11 octobre 2011. Courrier hebdomadaire du CRISP, 15/2013. http://dx.doi.org/10.3917/cris.2180.0005

Bönke, T. et al. (2013). Fiscal federalism and tax administration: Evidence from Germany. Discussion Paper n` 1307 , DIW Berlin. http://dx.doi.org/10.2139/ssrn.2294400

Central bureau of statistics. (2011). Population census 2011. Retrieved from http://cbs.gov.np/

Denil, F. et al. (2005). La théorie du fédéralisme fiscal et ses enseignements. In M. Mignolet (Ed.), Le fédéralisme fiscal. Leçons de la théorie économique et expérience de 4 États fédéraux (pp. 12-24). Brussels, Belgium: De Boeck Université.

Deutscher Bundestag. (1949). Basic Law for the Federal Republic of Germany. Retrieved from http://www.bundestag.be 
Federal Act of Swiss confederation. (1999). RO19992556. Retrieved from http://www.admin.ch/

Federal Law on financial equalization and compensation for financial burdens. (2003). RO20051481. Retrieved from http://www.admin.ch/

Federal Order on financial equalization and compensation for financial burdens. (2007). RO20075887. Retrieved from http://www.admin.ch/

Federal-Provincial Fiscal Arrangements Act. (1985). R.S.C., 1985, c. F-8. Retrieved from http://laws-lois.justice.gc.ca/

Government of Nepal. (2012). Consolidated financial statements of Fiscal Year 2011-2012. Retrieved from http://www.fcgo.gov.np/

Guihéry, L. (2005). Le fédéralisme fiscal allemand à la croisée des chemins: quelle issue entre fédéralisme coopératif et fédéralisme concurrentiel ? In M. Mignolet (Ed.), Le fédéralisme fiscal. Leçons de la théorie économique et expérience de 4 États fédéraux (pp. 12-24). Brussels, Belgium: De Boeck Université.

Gurung, H. (2008). Nepal: Atlas and Statistics (revised ed.). Kathmandu, Nepal: Himal books.

Hatlebakk, M., \& Ringal, C. (2013). The economic and social basis for state restructuring in Nepal. Kathmandu, Nepal: Himal Books.

Ley 22/2001, de 27 de diciembre, reguladora de los Fondos de Compensación Interterritorial. (2009, December 31). B.O.E. ${ }^{\circ} 313$. Retrieved from http://www.boe.es/

Ley 22/2009, de 18 de diciembre, por la que se regula el sistema de financiación de las Comunidades Autónomas de régimen común y Ciudades con Estatuto de Autonomía y se modifican determinadas normas tributarias (2009, December 19). B.O.E. $n^{\circ} 305$. Retrieved from http://www.boe.es/

Loi spéciale du 6 janvier 2014 portant réforme du financement des communautés et des régions, élargissement de l'autonomie fiscale des régions et financement des nouvelles compétences. (2014). M.B. 31/01/2014. Retrieved from http://www.ejustice.just.fgov.be/

Martinez, M. et al. (2014). Comparacion entre el federalisme economico regional de Belgica y Espana (Comparison between the Regional Economic Federalism in Belgium and in Spain). Revista Internacional Administracion $y$ Finanzas 7, 7(1), 1-29.

Nova Scotia and Newfoundland and Labrador Additional Fiscal Equalization Offset Payments Act. (2005). S.C. 2005, c. 30, s. 85. Retrieved from http://laws-lois.justice.gc.ca

Pagano, G. (2002). Le financement des Régions et des Communautés 1970-2002. Solidarité, responsabilité, autonomie et concurrence fiscale. Bruxelles, Belgique: CRISP.

Santiuste Vicario, A.I. (2011). La aplicación práctica del sistem de financiación de la Comunidades Autónomas de régimen común regulado en la Ley 22/2009, de 18 de diciembre. Instituto de Estudios fiscales. Retrieved from www.iefs.es

Spahn, P. B. (2012). Les partages de ressources entre l'État et les collectivités secondaires: le cas de la République fédérale d'Allemagne. Revue française d'administration publique, 2012/4, (144), 1071-1078. http://dx.doi.org/10.3917/rfap.144.1071

The Constitution Act. (1867). 30 \& 31 Victoria, c. 3 (U.K.). Retrieved from http://laws-lois.justice.gc.ca/

The Constitution Act. (1982). Retrieved from http://laws-lois.justice.gc.ca/

United Nations Development Programme. (2004). Nepal Human Development Report 2004 Empowerment and Poverty Reduction. Kathmandu, Nepal: United Nations Development Programme. Retrieved from http://www.undp.org/

Vandernoot, J. (2014). Funding of German Lander, Mechanisms and Solidarity. Research in Applied Economics, 6(2), 1-17. http://dx.doi.org/10.5296/rae.v6i2.5252

Van Wynsberghe, C. (2003). Les capitales fédérales, une comparaison. Revue internationale de politique comparée, 2003/1, 10, 63-77. http://dx.doi.org/10.3917/ripc.101.0063

\section{Notes}

Note 1. Provinces' names were not defined in the proposal. We will use the ones suggested by Hatlebakk et al.

Note 2. Narayani Province includes Kathmandu and its peripheral districts characterized by a high level of revenue per inhabitant. 